\title{
Papers
}

Explorations into Children's Literature

\section{The Charity of Witches: Watching the Edges in Terry Pratchett's Tiffany Aching Novels}

\section{Rebecca-Anne Do Rozario}

Terry Pratchett's final novel, The Shepherd's Crown, was published months after his death in 2015. The novel concludes the story arc of Tiffany Aching, hero of the Discworld children's/young adult novels that include The Wee Free Men (2003), A Hat Full of Sky (2004), Wintersmith (2006), and I Shall Wear Midnight (2010). The arc follows the heroine from the age of nine through her teenage years and although classified as children's or young adult novels, the novels merge seamlessly with the adult Discworld series. The novels' status within children's literature is sustained by a thematic core: Tiffany grows up. Her negotiation of childhood and adolescence, however, is shaped less by the valorisation of youth and desire for fame and fortune than by the example of old women and their dedication to public service. These old women are witches and they mind the margins of their community, as renowned witch Esmeralda Weatherwax explains of their work: "There're a lot of edges, more than people know. Between life and death, this world and the next, night and day, right and wrong....an' they need watchin'. We watch 'em, we guard the sum of things. And we never ask for any reward. That's important" (Pratchett 2010c). This article investigates how Pratchett draws on the history of fairy tales about witches and old women with their varied traditions of care and preservation, and reaches a narrative conclusion for the young heroine 
that rejects traditional fairy tale resolutions of romance, fame, or fortune. Instead, he endorses the heroic and everyday work performed at the 'edges.'

As a young girl, Tiffany aspires to be a witch, even though traditionally no witches can live on the Chalk, the land of Tiffany's birth. Witches are key in the Discworld series, existing in close relationship with their communities and stories. Three witches dominate the series: Esmeralda ‘Granny’ Weatherwax, Gytha 'Nanny’ Ogg, and Magrat Garlick. Pratchett's witches spring from a communal legacy of fairy tale, and Discworld novels featuring the witches therefore focus upon folk and fairy-tale themes. ${ }^{1}$ In Witches Abroad (1991), for example, the witches travel to Genua to defeat a fairy godmother, Lilith, who is forcing people and animals into popular fairy-tale roles. As Granny remarks of Lilith's aspirations, “you don't build a better world by choppin' heads off and giving decent girls away to frogs" (Pratchett 2010a). The operation of story is unfailingly significant in witch-led narratives, informing activities and philosophies. Elisabeth Rose Gruner, for instance, argues that Granny's "stories are compassionate, part of a caregiving ethic of meeting her charges where they are and giving them what they need" (2011, p.287). Stories can be used to understand and manage danger to the community, a form of knowledge that Tiffany shares and employs in her dealings with fairy queens, hivers, the Wintersmith, and elves. The recognition, understanding, and perpetuation of story thus informs witch-led activity in the community. Pratchett's witches are constructed in the spirit of Mother Gooses and Mother Bunches, ancient figures who operate as storytellers and nurses, repositories of old wives' wisdom, practical knowledge, and insight regarding birth, sex, and death. Pratchett's witches derive their power from their place in the stories.

\footnotetext{
${ }^{1}$ The Discworld novels cover a vast cast of characters and places. Individual novels tend to focus on certain sets of characters. The witches feature in Equal Rites (1987), Wryd Sisters (1988), Witches Abroad (1991), Lords and Ladies (1992), Maskerade (1995) and Carpe Jugulum (1998), as well as in the Tiffany Aching novels.
} 
The sobriquets of both Granny Weatherwax and Nanny Ogg echo these appellations of 'Mother,' being less invested in actual procreation than in a representation of maternal/feminine wisdom and experience in the community best exemplified by the elderly woman. Although never explicitly stated, Pratchett's witches value and even covet old age. In Equal Rites, "Granny suffered from robustly healthy teeth, which she considered a big drawback in a witch. She really envied Nanny Annaple, the witch over the mountain, who managed to lose all her teeth by the time she was twenty and had real crone-credibility" (Pratchett 2009). The desire for crone-credibility informs the Tiffany Aching novels. In the first novel, the Nac Mac Feegle, a race of small, blue fairies who enjoy fighting and stealing dub the nine-year-old Tiffany their big wee hag, identifying her as a wise woman/witch with an epitaph that infers old age. The title of I Shall Wear Midnight quotes Tiffany: "when I am old I shall wear midnight” (Pratchett 2010f). Tiffany's desire adapts Jenny Joseph's iconic poem, "Warning" (1961), in which she asserts, "When I am an old woman I shall wear purple" (1997). Tiffany sees old age as brimming with possibility, autonomy, and license:

"Sometimes, Tiffany thought, I am so fed up with being young" (Pratchett 2015). Wisdom and experience implied by old age provides the authority to dispense advice and assistance. The witches, even the youngest witches, instinctively align themselves with the authority of crones, embodied in the elderly Mother figures of fairy tale.

Nanny Ogg, a midwife who provides Tiffany with romantic advice regarding Roland and the Wintersmith, is a particularly close correlation with Mother Bunch, a crone renown for her listening skills and freely dispensed sexual stories and advice. Mother Bunch evolved from the advisor and fortuneteller of Pasquil's Jests and Mother Bunch's Merriments (1604) and Mother Bunch's Closet Newly Broke Open (1685) into the storytelling figurehead of Mother 
Bunch's Fairy Tales (1773). ${ }^{2}$ Jennifer Schacker notes that through Mother Bunch's transitions, she "is a highly self-aware and skilled orator" (2011, p. 258). Nanny Ogg, however, takes this a step further with her assertive listening skills: "Witches soon picked up ways of controlling people with their voice, but Nanny Ogg listened at you" (Pratchett 2010e). Nanny Ogg evokes Mother Bunch's early appearances as an ale-wife of generous girth and occasional flatulence, a wife who has had many husbands. Clear parallels exist between the alewife and Pratchett's witch. In Maskerade (1995), Nanny has published a 'cookbook' containing recipes liberally laced with sexual innuendo and anecdotes. Separately published in its own right, Nanny Ogg's Cookbook (1999) includes, for example, her recipe for Maids of Honour, which warns “[t]ake your eye off 'em and they end up as tarts" (Pratchett 2012). Her Strawberry Wobbler is best left to the imagination. Mother Bunch provides spells and recipes in the more antiquated sense, advising maidens on the finding of husbands, where "[a] mixture of bawdy and practical common sense for the avoidance of trouble was never far absent" (Spufford 1981, p. 61). Nanny and Mother Bunch also share a strong association with drinking. Nanny enjoys a drink and one of her most famous recipes is for Scumble Cider. Spufford likewise locates Mother Bunch in England's alehouses: "The alehouse keeper is a key figure in the process of disseminating news and stories and therefore in the world of cheap print. Mother Bunch is the most magnificent teller of tall stories amongst the alehouse keepers" (1981, p. 66). Schacker notes her further influence upon women: "Mother Bunch's power is infectious, and as producer and dispenser of the strong ale that bears her name, she is rumored to have had the most profound effect on her female patrons" (2011, p. 258). Both Nanny and Mother Bunch serve as the main source of sexual advice for, particularly, young women: they are gregarious, domineering, heavy-drinking, wise women. Their support and

\footnotetext{
${ }^{2}$ The latter tales themselves were translations of the work of Marie-Catherine d'Aulnoy, the sophisticated, aristocratic author of the seventeenth century.
} 
instruction is freely provided, providing women with a range of accessible family planning services in communities that lack public healthcare.

Granny Weatherwax, on the other hand, operates within the tradition of old maids, aligning her with the respectable, sometimes austere, Mother Goose figure that emerged after Charles Perrault's attribution of his stories to her in Tales of Times Past (1697). Warner notes that "[t]he immemorial storyteller, Mother Goose, or Mother Stork, or Mother Bunch, is a figure of fun, a foolish, ignorant old woman, a typical purveyor of old wives' tales. But she is also established, by the early eighteenth century, as a Sibyl-Nurse - who instils morality and knowledge of the world, and foresees the future of her charges and prepares them for it" (1995, p. 79). The acerbic Granny embodies this early eighteenth-century figure and Granny, like all witches, foresees and prepares for her death, just as the Sibyl is reported to have foretold her death, with some myths maintaining that her voice lingered after her body's loss. Neil Gaiman revealed that Pratchett actually planned for Granny to linger after her death, too, in The Shepherd's Crown, borrowing the body of her cat in order to supervise Tiffany's transition to 'head witch' (Vincent 2015). Indeed, Granny's ability to borrow the form of animals mimics Mother Goose's own shapeshifting from old woman to anthropomorphised goose. Mother Goose also, over time, acquired a broomstick to ride and a pointy black hat to wear, enhancing her resemblance to the figure of the witch. In effect, the good persona of Mother Goose and the wickedness of the witch merged in children's book illustrations of old women with sharp noses. Granny represents the duality: she inspires terror and performs good works.

It is the work, rather than age or social status, that ultimately defines a witch since not all witches in the Discworld series are chronologically old, and some even occupy the fairy tale 
role of princess. Magrat Garlick, embodying romantic, quasi-wiccan qualities with her rattling jewelry and green silk gowns, weds the fool-cum-king of Lancre. The Baron's son, Roland, initially Tiffany's love interest, weds Letitia Keepsake who, it transpires, is also a witch. In The Shepherd's Crown, both Letitia and Magrat are called upon to move beyond social and marital roles to act against an incursion of elves. Letitia resists: "I am the Baroness. I am a lady. I can’t be a witch" (Pratchett 2015). Magrat responds, “I am a queen. That doesn't stop me being a witch when needs must. This is the time, my dear, when we stop thinking about ourselves and who we are and get down and dirty" (Pratchett 2015). Witches respond selflessly to occasions of need in their communities.

Even so, the Discworld remains dominated by the singular, stereotypical image of the wicked witch: "old stories, old rumors and old picture books still seemed to have their own hold on the memory of the world" (Pratchett 2010f). This is the "problematic location of witches in story” that Caroline Webb recognises (2006, p.156). Tiffany's fairy-tale book, The Goode Childe's Booke of Faerie Tales, mirrors the kinds of sanitised, often stereotypical, hypermoralising, and faux-ancient fairy-tale collections published for children in the nineteenth and twentieth centuries, often identified as Mother Goose collections. Tiffany muses that "all the stories had, somewhere, the witch. The wicked old witch" (Pratchett 2010c). Although the witches are all old and wicked, with her brown hair and plain face disqualifying her for the role of princess, Tiffany sensibly decides to "be the witch and know things" (Pratchett 2010c). As Tiffany innately knows, Pratchett's witches are identified not by the external or physical qualities indicated in stories, but by the quality of their minds, and all minds are unique. Despite the weight of cultural prejudice, Pratchett's witches complicate the stereotype. 
That stereotype of the wicked witch is not rejected by Pratchett, but deconstructed and then revitalised, drawing on a complicated history of representation that ultimately embraces the power of the witch. Elisabeth Gruner suggests that "Pratchett reanimates what might have been thought to have devolved into fairy tale, legend, and superstition" (2011, p. 286). Wily old women and powerful fairies had merged into the figure of the wicked witch so familiar in the Grimms' fairy tales of the nineteenth century. Jack Zipes notes that "[t]he alteration of the stories about fairies and witches connected to good goddesses by inquisitors, clerics, authorities, intellectuals, and other 'educated' prosecutors was common throughout Europe" (2012, p. 75). Pratchett's novels acknowledge the stereotypes of the wicked witch that emerged from this period of vilification. Tiffany questions these stereotypes from the outset: "The stories never said why she was wicked. It was enough to be an old woman" (Pratchett 2010c). Tiffany recognises the history of injustice and prejudice in telling Miss Tick about Mrs Stapperly, an elderly woman attacked for being a witch and then left to die alone in the cold. Yet, the witches do embrace aspects of the wicked witch stereotype that lend them authority and power. Indeed, Granny Weatherwax enjoys evoking fear, imparting its value to Tiffany: "A witch ought never to be frightened in the darkest forest $[\ldots]$ because she should be sure in her soul that the most terrifying thing in the forest was her" (Pratchett 2010e).

Notable in the discussion thus far, Pratchett's witches are exclusively female. Diane Purkiss argues, "When early modern women thought about witches and constructed their figurations of witchcraft, their fantasies reflected the need to establish or maintain a social identity within the community" (1996, pp. 93-94). Purkiss contends that while the role of women was constrained to the domestic: "within this circumscribed space a rich and elaborate network of cultural meanings was assigned to productive tasks," and within the network, "a witch was a figure who could be read against and within her own social identity as housewife and mother" 
(1996, p. 94). The Tiffany Aching books, in particular, offer such a world of women conspiring to create not simply a distinct identity for themselves as witches of their communities, but likewise a benevolent, useful space, in which the witch assists her neighbours with freely provided medical and veterinarian assistance, and further encourages networks to evolve in which people take responsibility for their own lives. Tiffany explains 'witching' to her father: 'Grasp for them as can't bend, reach for them as can't stretch, wipe for them as can't twist' (Pratchett 2010f). Although Tiffany often grumbles about cutting toe nails for the elderly - 'sometimes an old boy without friends or family would have this toenails twisting inside his boots' (Pratchett 2015) - she likewise articulates her love for the work, work that Granny Weatherwax positively asserts as 'women's work.' Pratchett's witches have, in effect, evolved from the early modern history Purkiss describes. Webb argues, 'For Pratchett, it is this ethic that defines the witch: rather than being simply a social reject or a cursing crone, the witch takes responsibility for the well-being of the community. Outside the community only in so far as she sees beyond it, the witch oversees the life of her society' (2006, p. 157). The witch need not be likeable, she may even intimidate and unnerve, but she will take charge of her community's welfare.

The male magical counterparts of the witches are not driven by the same attitudes towards community. The wizards are based at the Unseen University in Ankh-Morpork, the most cosmopolitan, unsavoury city on the Discworld. Wizards are urban-based scholars, usually greedy and lazy, with younger wizards experimenting in magical equivalents of the hard sciences, while the witches are based in their own, usually rural and small-town territories, performing women's work. Lian Sinclair argues that 'gender must be central to any treatment of witches' (2015 p. 11). The gender binary maintained in Discworld's magical community, however, does not beg that question of gender as often in examination of the wizards, who 
quite explicitly and indolently exploit male privilege, and Granny Weatherwax is herself against challenging gender roles in Equal Rites (1987). She insists on maintaining the binary when presented with a girl, Esk, who wishes to be a wizard: 'wizard magic, it's all books and stars and jommetry. She'd never grasp it. Whoever heard of a female wizard?' (Pratchett 2009). Yet Granny does not position witch's magic as inferior: 'magic out of the ground, not the sky, and men never could get the hang of it' (Pratchett 2009). The essentialist gender division in Equal Rites, itself an early novel in the series, is persistent and Granny represents a conservative view of gender, one with little tolerance for masculine roles, but the view is not unchecked, and later novels continue to renegotiate constructions of gender. ${ }^{3}$

While Granny Weatherwax dismisses book learning, so beloved of the wizards, and is apt to make mistakes in spelling and punctuation, for instance, many witches in fact do read and even write books. Miss Tick, for example, counts her 'tendency to correct other people's pronunciation' (Pratchett 2010c) among her witch-qualities and quietly condemns the burning of a suspected witch's astronomy books. However, witches do not have a 'school' like the Unseen University, and are apprenticed to established witches, being expected to perform practical tasks. Granny's bias against books and education is actually a more extreme manifestation of the witches' disdain for knowledge without application - for knowledge that isn't, essentially, practical. She scoffs, 'Books? What good are they? There's too much reading these days. We never had time to read when we was young' (Pratchett 2010b). Witches, like Lettice Earwig, who focus more upon mystical talismans and chants,

\footnotetext{
${ }^{3}$ Pratchett's final novel, The Shepherd's Crown, published 34 years later, features a young man, Geoffrey, who wishes to be a witch. Geoffrey's relation of gender implies Pratchett was about to further question the gender constructions represented in his magical community: 'I've never thought of myself as a man, Mistress Tiffany. I don't think I'm anything. I'm just me' (Pratchett 2015). Characters such as Esk and Geoffrey are unusual, however, and the magical gender binary is virtually unassailable. Indeed, Esk becomes a witch again, appearing in I Shall Wear Midnight.
} 
the kind of paraphernalia favoured by wizards, are frequently dismissed by their peers, particularly by the likes of Granny and Tiffany. Experience and knowledge of stories, rather than book-learning, is what matters.

In The Wee Free Men, Granny Weatherwax asserts that witchcraft is 'not like school at all. First you get the test, and then afterwards you spend years findin' out how you passed it. It's a bit like life in that respect' (Pratchett 2010c). Indeed, life provides the material of their training. While Tiffany does seek to 'know things,' the witches learn through hard work in their communities, rather than through scholarly application. Tiffany is apprenticed to Miss Level in order to 'learn proper witching' and sells this to her parents as going into service: 'Traditionally, you started by helping an old lady who lived by herself' (Pratchett 2010d). The analogy between apprenticeship and service to an old lady is apt in terms of fairy-tale traditions. Maria Tatar notes of Baba Yaga tales, for instance, ' $[\mathrm{t}]$ he lesson about the rewards to be reaped from hard work, humility, modesty, and kindness while in the service of an allpowerful female figure' (1993, p. 56). Miss Tick enforces the value of hard work in her advice to Tiffany, too, warning that if you believe in dreams and follow stars - the kind of mantra behind the songs Disney princesses sing - 'you'll still get beaten by people who spent their time working hard and learning things' (Pratchett 2010c). Tiffany, slated to be a great witch, is capable of exceptional magic and defeats many formidable foes, but she spends the bulk of her time working with the elderly, the sick, and pregnant mothers. Webb notes that belief in everyday work and service is itself a form of magic: 'Paradoxically, Mistress Weatherwax's own passionate conviction that the centre of witchcraft is helping people with daily life and not with magic is expressed with a fervour that seems to have magical effects' (2015, p. 109). It is the magic, effectively, of women's work. 
Contrasted to the self-indulgent, ambitious lives of wizards, isolated in the Unseen University, the witches are active and hard working in their communities, comfortable if not affluent in their circumstances, and they take an interest in each other, particularly to ensure that the burdens of caring for the community do not overwhelm them. Cackling is one of the greatest fears a witch faces and is rooted in their working lives: 'It meant loneliness and hard work and responsibility and other people's problems driving you crazy a little bit at a time, each bit so small that you'd hardly notice it, until you thought that it was normal to stop washing and wear a kettle on your head' (Pratchett 2010e). The witches deal constantly with domestic and rural trauma and isolation, and this has a profound impact upon their lives. Tiffany reflects in The Shepherd's Crown that '[t]he main difference [between wizards and witches] was that wizards used books and staffs to create spells, big spells about big stuff, and they were men. While witches - always women - dealt with everyday stuff. Big stuff too, she reminded herself firmly' (Pratchett 2015). Webb argues that the earlier novel, A Hat Full of Sky, 'bears out the idea that there is something intrinsically more interesting about dealing with magical beings than about living like a cross between a district nurse and community social worker' (2015, p. 109), but although narrative action in the series focuses upon magical adventure, the narratives themselves persistently enforce that while perhaps less interesting, work in the community is 'big stuff.' Tiffany's mental defence reveals a continued sense of unease, explored throughout the series, about the lack of status accorded women's daily, compassionate work.

Granny's maintenance of an essential gender distinction between approaches to magic presents feminine magic as superior. Granny continuously asserts the everyday, the work of women, as big and important. Male wizards, on the other hand, are frequently described, even by themselves, as being of little practical use. In Lords and Ladies their magic is summarised 
thus: 'wizards talk about candles, circles, planets, bananas, chants, runes and the importance of having at least four good meals every day' (Pratchett 2010b). Wizards do contribute to society and frequently deal with metaphysical threats and phenomena, but on the whole tend to be patriarchal, insular, and gourmandising. Each Discworld novel prioritises one approach to magic over the other, depending upon the setting and the threat presented in the narrative. In Lords and Ladies, for instance, in which the Archchancellor of the Unseen University visits Lancre for the Royal Wedding, his activities remain subordinate to the those of the witches, who are on their home ground and must defeat an onslaught of elves. Pratchett maintains the distinction between wizards and witches, keeping their spheres of magic largely separate. Although Imola Bulgozdi argues that 'Pratchett's female characters are often depicted in the process of pushing back patriarchal boundaries and attempting to solve problems specifically caused by their gender' (2013 p. 206), such problems are actually much more apparent in novels dealing with Ankh-Morpork, the patriarchal heart of the Discworld, in which women strive to occupy positions traditionally held by men. The witches bolster their independence from patriarchy by privileging roles and attributes traditionally identified as feminine.

Tiffany is consequently alert to gender norms and must negotiate the expectations of gender with which she has been enculturated. At nine years of age, for example, Tiffany worries that the china shepherdess she gave her recently deceased grandmother, Sarah 'Granny' Aching, was offensive. Granny Aching was a shepherd who lived in a wheeled hut in the hills with her dogs, an old woman who cussed and drank and dressed practically for rough weather. The china shepherdess, on the other hand, is a dainty young woman in frills and ribbons, the perfect representation of a woman as an object of aesthetic value. Tiffany thinks, 'Perhaps she thought she was being told that this was what a shepherdess should look like. She 
shouldn't be an old lady in a muddy dress and big boots, with an old sack around her shoulders to keep the rain off [...] she'd never meant to, but perhaps she had been telling Granny that she wasn't... right' (Pratchett 2010c). In effect, Tiffany worries that she has implied Granny does not fulfill feminine norms. However, much like any older witch, Granny Aching takes a feminine norm and makes it powerful. ${ }^{4}$ When Tiffany battles the fairy queen, Granny's 'spirit' comes to her aid, wearing the costume of the china shepherdess: 'Tiffany saw that while she was a brilliant, glowing shepherdess from hat to hem, she still had her huge old boots on' (Pratchett 2010c). Granny adroitly claims and embodies the ribbons and ruffles of the china shepherdess, 'glowing with pride' (Pratchett 2010c). There is no shame: Granny can manifest feminine norms while keeping her practical boots firmly on her feet.

Lori M. Campbell says

male authors such as Alan Garner, Terry Pratchett, Neil Gaiman, and Philip Pullman began writing about women and girls in more enlightened, less rigidly stereotypical ways. Out of these combined efforts rose a character type who could live up to the mantle of hero, one displaying bravery, assertiveness - and, at times, foolishness or arrogance - all familiar traits of her male counterpart, but also human traits shared by all'. (2014 p. 5)

However, in Pratchett's novels, the mantle of hero is represented as specifically feminine. When Tiffany bravely and capably handles a case of domestic violence, her father, recognising the importance of her work, praises her for doing 'a man's job' (Pratchett 2010f). He assumes that important work must be men's work. Her father's assumption is deftly corrected at the end of the novel when Granny approves of Tiffany's efforts by declaring she

\footnotetext{
${ }^{4}$ Although Granny Aching is not an official witch, Granny Weatherwax views her as the next best thing to a witch.
} 
is doing 'a woman's job' (Pratchett 2010f). While much attention is given to texts that challenge the gender binary, Pratchett's witches uphold the great importance of women's work. In the witches' novels, to be female and to work hard and without compensation in the domestic, everyday world is not to be subjugated, limited, or unambitious. It is not to be less than a man: it is to be better than a man.

Pratchett's witches enthusiastically pursue and perfect traditionally feminine roles including those of family matriarchs, midwives, teachers, and nurses. Sanna Lehtonen argues Pratchett's 'rewriting the evil witch stereotype by introducing a good witch ... follows a fairly traditional feminine career path of nursing and healing' (2013, p. 70). The rewriting itself is explicit in the narrative emphasis on story, as Gruner suggests: the healing freely offered by the witches is couched in stories and in the rewriting of stories and ' $[\mathrm{t}] \mathrm{he}$ storybook pictures of the drooling hag were being wiped away, every time Tiffany helped a young mother with her first baby, or smoothed an old man's path to his grave' (Pratchett 2010f). However, again, this is about more than simply rewriting the wicked witch as good: 'Granny was an old-fashioned witch. She didn't do good for people, she did right by them' (Pratchett 2008). Janet Brennan Croft corroborates that ' $[\mathrm{t}]$ he philosophy and ethics of witchcraft are firmly based on striving for Rightness' (2008, p. 161). The point Pratchett elaborates is that the witches do what is necessary and important, not what is simply good, and thus the work of healing is rooted in pragmatism - tough love, essentially. Femininity and women's work is disengaged from simple moral concepts of goodness, which is why the witches never completely repudiate their wickedness. Gruner argues: 'The witches know, as most of the men around them seem not to, that caring for others involves both story and dirt, both the 'whizzing about' that is part of every story about witches and cutting old ladies' toenails - which doesn't make it into the stories but is just as important' (2011, p. 289). The 
moral ambiguity of the witch is rooted in her service in the community: she doesn't have to be good to do women's work, work just as important as any magical exploit.

A delicate balance exists between Pratchett's witches and the communities they serve. Zipes notes the jumbled tradition of fairies and witches, goodness and evil. He describes, for instance, the Sicilian 'ladies from the outside' who 'belonged to a dualistic system of widespread belief and could cause harm or perform good deeds. Even if fairy/witches caused harm, there were ways through offerings or expiation to repair the damage' $(2012$, p. 74$)$. This balance is exemplified in Wintersmith: 'Blessings be upon this house,' said Granny, but in a voice that suggested that if blessings needed to be taken away, she could do that, too' (Pratchett 2010e). While the witches do not charge for their services, they expect and are provided with food and good, used clothing, both as thanks and to encourage future good will. The weight of witching, however, isn't to be lightly entered into, and Tiffany has doubts in Wintersmith: 'I don't want to be a kind of slave to people who can't be bothered to think for themselves; I don't want to wear midnight and make people afraid of me' (Pratchett 2010e). The witches are not in service to their own self-interest, as is largely the case with wizards, but to their communities. Although not officially identifying as a witch, Granny Aching prioritises her obligation to the sheep and other animals: 'we are as gods to the beasts o' the field, my jiggit. We order the time o' their birth and the time o' their death. Between times, we ha' a duty' (Pratchett 2010c). In Lords and Ladies, Pratchett considers the implications of duty: 'If you want to really upset a witch, do her a favour which she has no means of repaying. The unfulfilled obligation will nag at her like a hangnail' (Pratchett 2010b). Obligations and bargains are, for the witches, the stimulus of community service and Eileen Donaldson notes: 'Rather than being monsters, Pratchett's witches are therefore helpful figures in this series' (2014, p. 149). Thus, when Tiffany is accused of the selfishness of 
witches, she tells herself, 'Then turn selfishness into a weapon! Make all things yours! Make other lives and dreams and hopes yours! Protect them! Save them!' (Pratchett 2010c). While Webb argues that Tiffany claims selfishness, usually perceived as a negative quality, 'as a strength' (2015, p. 36), this claim is also grounded in the ethics of witches. Selfishness and potential wickedness is continually tempered by obligation.

Such obligations and rewards, however, are not simply tied to capitalism. This marks Pratchett's greatest departure from the common rhetorical strategy of fairy tale, whereby a heroine will be rewarded by fairies and witches with dresses of gold, rubies falling from her lips, or handsome and wealthy princes. Matthew Grenby notes of many moral tales for children that 'Charity had become a fiscal transaction rather than moral duty, commendable because it signified a child's economic rationalism rather than any open-hearted benevolence' (2008, p. 71). Tiffany's curiosity, bravery, and general precociousness leads her not to a life of wealth and reward, initially suggested by her rescue of and consequent friendship with the Baron's son, but to a life of service. She works on her family farm as a child, well known for her knack with making cheese. She obtains education by bartering an egg or carrot for the occasional lesson from the travelling teachers. Her childhood in a society coming to terms with increasing industrialisation, and urbanisation is marked by rural deprivation and child labour, though it is never framed as such. Christopher Parkes, writing of nineteenth-century children's literature, argues: 'The solution to the problem of the child as a victim of commercialism and industrialization came $[\ldots]$ in the form of a rhetorical strategy that equated the spirit of capitalism with the spirit of childhood' with children consequently 'defined by an innate curiosity and invention, the kind that leads to capitalist innovation' (2012, p. 1). Pratchett valorises Tiffany's community service over innovation and wealth gains. Tiffany does the jobs no one else wants, creating a role for herself based on the 
community's needs: 'she had made herself the witch because they needed one' (Pratchett 2010f). There is no immediate, material, or emotional reward for the work that is performed. The witches act in line with their sense of obligation to the community: 'Going around the houses - that was what you did if you were a compassionate witch, what she and all the other witches did to fill in the gaps in the world, doing things that had to be done' (Pratchett 2015).

Traditionally, fairy tale conclusions for young women involve marriage, reaffirming heteronormativity and patriarchy. ${ }^{5}$ Pratchett, however, focuses his narratives more intently upon the structures of marriage that inform communal cohesion and turmoil, the structures the witches must navigate in their work. Warner notes: 'The weddings of fairy tale bring the traditional narratives to a satisfying open ending which allows the possibility of hope; but the story structure masks the fact that many stories picture the conditions of marriage during the course of their telling' (1995, p. 219). In the Tiffany Aching novels, a wide variety of marriages are explored, from the domestic equanimity of Tiffany's parents' marriage to the Pettys' abusive relationship. Tiffany is briefly engaged, has a short, platonic relationship with Roland, and during the final two novels develops a romantic relationship with medical student, Preston, during which she meditates upon her own marriage prospects as a witch. The latter relationship is hindered by both parties being busy caring for the unfortunate, and although her story does not preclude the future possibility of marriage, it does not conclude with it. Preston remains apprenticed at the Lady Sybil Free Hospital and Tiffany acknowledges that they both love what they do: 'you might say we are our work' (Pratchett 2015). Indeed, she notes of witches: 'most of the older ones Tiffany knew hadn't got married either, mostly because Nanny Ogg had already used up all the eligible husbands, but also probably because they didn't have time' (Pratchett 2010f). The message is that witches are

\footnotetext{
${ }^{5}$ Of course, many tales actually challenge heteronormativity and patriarchy, including Catherine Bernard's 'Riquet with the Tuft' (1696).
} 
usually too busy for a marriage resolution and even when they do wed, like Nanny Ogg and Magrat, they simply carry on being witches.

In the absence of an immediate marriage resolution, Tiffany's relationship with her grandmother shapes her future: 'I can't help thinking about Granny Aching and how much she liked her life, up on the downs, just her and the sheep and her two dogs' (Pratchett 2015). At the conclusion of The Shepherd's Crown, Tiffany quite literally rejects filling recentlydeceased Granny Weatherwax's boots as head witch: 'there they sat, almost staring at her when she was too weary to think. You're not good enough yet to fill these boots, they seemed to say' (Pratchett 2015). Where fairy tale heroines may seek glass slippers and red shoes, the witches aspire to 'good, sensible boots' (Pratchett 2015). Throughout the novel, she is torn between Granny's cottage and the Chalk, overworked serving both communities. By the end of the novel, she concludes that she is part of the Chalk and should remain there, so builds her own shepherding hut in the image of her grandmother's and sets it up where her grandmother's hut once stood. She fills her own grandmother's boots. Tiffany's father even offers her a bottle of special sheep liniment, a homebrew for which Granny Aching was well known. Tiffany is not, after all, following in the more virtuous path of Mother Goose, but possibly in the rather more boisterous path of Mother Bunch. Her tale ends as she settles into her life as witch of the Chalk. Marriage is not renounced, but Tiffany's happy ending is the building of her own shepherd's hut and her continued service to her community.

In the final Tiffany Aching novel, the fairy Peaseblossom taunts the heroine: 'We elves knew well of the witch who once walked the edges of this world... but you, you are just a child' (Pratchett 2015). Tiffany, however, is not simply a child. She is a witch. In being a witch, she draws upon the traditions of old women who terrify and serve their communities, women 
who represent the strength and importance of traditional women's work. While many children's novels celebrate male heroism, rewards of wealth, and marital conclusions, Pratchett revitalises older fairy tale traditions of wise old women to valorise public service and care for the community. Tiffany Aching is a heroine representing profoundly feminine charity and hard work.

Reference List

Bulgozdi, I 2013 “"Barbarian Heroing” and Its Parody: New Perspectives on Masculinity’, in Conan Meets the Academy: Multidisciplinary Essays on the Enduring Barbarian, $\mathrm{J}$ Prida (ed.), McFarland \& Company, Jefferson, pp. 193-211.

Campbell, LM 2014 'Introduction', in A Quest of Her Own: Essays on the Female Hero in Modern Fantasy, LM Campbell (ed.), McFarland \& Company, Jefferson, pp. 4-14. Croft, JB 2008 'Nice, Good, or Right: Faces of the Wise Woman in Terry Pratchett's “Witches” Novels', Mythlore vol. 26, no. 3/4, pp. 151-164.

Donaldson, E 2014 'Earning the Right To Wear Midnight: Terry Pratchett's Tiffany Aching', in The Gothic Fairy Tale in Young Adult Literature: Essays on Stories from Grimm to Gaiman, J Abbruscato \& T Jones (eds.), McFarland \& Company, Jefferson, pp. 145163.

Grenby, MO 2008 Children's Literature, Edinburgh University Press, Edinburgh.

Gruner, ER 2011 'Wrestling with Religion: Pullman, Pratchett, and the Uses of Story', Children's Literature Association vol. 36, no. 3, pp. 276-295.

Joseph, J 1997 (1961) Warning: When I am an Old Woman I Shall Wear Purple, Souvenir, London. 
Lehtonen S 2013 Girls Transforming: Invisibility and Age-Shifting in Children's Fantasy Fiction Since the 1970s, McFarland \& Company, Jefferson.

Parkes, C 2012 Children's Literature and Capitalism: Fictions of Social Mobility in Britain 1850-1914, Palgrave Macmillan, London.

Pratchett, T 2009 (1987) Equal Rites, Transworld Digital, London. Available from: Kindle. [21 December, 2015].

Pratchett, T 2010a (1991) Witches Abroad, Transworld Digital, London. Available from: Kindle. [21 December, 2015].

Pratchett, T 2010b (1992) Lords and Ladies, Transworld Digital, London. Available from: Kindle. [21 December, 2015].

Pratchett, T 2010c (2003) The Wee Free Men, RHCP Digital, London. Available from: Kindle. [21 December, 2015].

Pratchett, T 2010d (2004) A Hat Full of Sky, RHCP Digital, London. Available from: Kindle. [21 December, 2015].

Pratchett, T 2010e (2006) Wintersmith, RHCP Digital, London. Available from: Kindle. [21 December, 2015].

Pratchett, T 2010f I Shall Wear Midnight, RHCP Digital, London. Available from: Kindle. [21 December, 2015].

Pratchett, T 2015 The Shepherd's Crown, RHCP Digital, London. Available from: Kindle. [21 December, 2015].

Pratchett, T, Briggs, S, Kidby, P and Hannan, T 2012 (1999) Nanny Ogg's Cookbook, Corgi, London. Available from: Kindle. [21 December, 2015].

Purkiss, D 1996 The Witch In History: Early modern and twentieth-century representations, Routledge, London. 
Schacker, J 2011 'Fluid Identities: Madame d'Aulnoy, Mother Bunch, and Fairy-Tale History', in The Individual and Tradition: Folkloristic Perspectives, R Cashman, T Mould \& P Shukla (eds.), Indiana University Press, Bloomington, pp. 249-263.

Sinclair, L 2015 'Magical Genders: The Gender(s) of Witches in the Historical Imagination of Terry Pratchett's Discworld', Mythlore vol. 33, no.2, pp. 7-20.

Spufford, M 1981 Small Books and Pleasant Histories: Popular Fiction and its readership in Seventeenth-Century England, Cambridge UP, Cambridge.

Tatar, M 1993 Off With Their Heads: Fairy Tales and the Culture of Childhood, Princeton UP, Princeton.

Vincent, A 2015 'Neil Gaiman reveals the real ending Terry Pratchett wanted for The Shepherd's Crown', The Telegraph, 28 August. www.telegraph.co.uk. [29 February 2016].

Warner, M 1995 From the Beast to the Blonde: On fairy tales and their tellers, Vintage, London.

Webb, C 2006 "“Change the Story, Change the World”: Witches/Crones as Heroes in Novels by Terry Pratchett and Diana Wynne Jones', Papers: Explorations in Children's Literature vol. 16, no. 2, pp. 156-61.

Webb, C 2015 Fantasy and the Real World in British Children's Literature: The Power of Story, Taylor \& Francis, New York.

Zipes, J 2012, The Irresistible Fairy Tale: The Cultural and Social History of a Genre, Princeton UP, Princeton. 


\section{Biographical Note}

Rebecca-Anne C. Do Rozario is a lecturer at Monash University where she teaches fairy tale and children's literature. She has published in edited collections such as On the Highways to Hell and Back: Critical Essays on the Television Series Supernatural and The Gothic in Children's Literature: Haunting the Borders, and in journals including Children's Literature, Marvels \& Tales, TDR: The Drama Review, and Nineteenth Century Contexts: An Interdisciplinary Journal on topics including Disney princesses, Australian fairy tales, pantomime and musical theatre. 